\title{
Variability of marine biological productivity in the northeastern Pacific over the past millennium
}

\section{Variabilidad de la productividad biológica marina en el Pacífico nororiental durante el último milenio}

\author{
Miryam Juárez ${ }^{1}$, Alberto Sánchez ${ }^{1 *}$, Oscar González-Yajimovich² \\ ${ }^{1}$ Centro Interdisciplinario de Ciencias Marinas (CICIMAR), Instituto Politécnico Nacional, Av. IPN S/N, Col. \\ Playa Palo de Sta. Rita, CP 23096 La Paz, BCS, México \\ ${ }^{2}$ Facultad de Ciencias Marinas, Universidad Autónoma de Baja California (UABC), Carretera Tijuana- \\ Ensenada Km 103, CP 22800 Ensenada, BC, México \\ * Corresponding author. E-mail: alsanchezg@ipn.mx; alsanchezg13@gmail.com
}

\begin{abstract}
In this study we present new data of biogenic opal (BO), organic carbon $(\mathrm{OC})$, and calcium carbonate $\left(\mathrm{CaCO}_{3}\right)$ in a highresolution record from the western coast of Baja California Sur, Mexico. The variability of marine biological productivity in this area is dominated by El Niño and La Niña events on different time scales. The BO and OC contents showed a decrease between AD 1100 and 1400. From $\mathrm{AD} 1400$ to the present, $\mathrm{BO}$ and $\mathrm{OC}$ showed a significant increase, indicating permanent upwelling conditions. The $\mathrm{CaCO}_{3}$ content showed an inverse correlation with $\mathrm{OC}$, which suggests that the exported $\mathrm{OC}$ fluxes are a significant factor controlling $\mathrm{CaCO}_{3}$ dissolution in the sediment. The increase in BO and OC was synchronic with a decline in the number of El Niño events (6 \pm 4 every 100 years) over the last 600 years of the millennium.
\end{abstract}

Key words: biogenic opal, organic carbon, El Niño, La Niña, upwelling.

RESUMEN. En este trabajo se presentan nuevos datos de un registro de alta resolución de ópalo biogénico (OB), carbono orgánico (CO) y carbonato de calcio $\left(\mathrm{CaCO}_{3}\right)$ en la costa occidental de Baja California Sur, México. En esta región, la variabilidad de la productividad biológica marina es dominada por la intensidad de los eventos El Niño y La Niña en diversas escalas de tiempo. Los contenidos de OB y CO disminuyeron durante el periodo de AD 1100 a 1400. En el periodo de AD 1400 al presente, el OB y CO aumentaron significativamente, lo cual indica condiciones permanentes de surgencia. El contenido de $\mathrm{CaCO}_{3}$ se correlacionó inversamente con el $\mathrm{CO}$, y esto sugiere que los flujos de $\mathrm{CO}$ exportado son un factor significativo que controla la disolución de $\mathrm{CaCO}_{3}$ en el sedimento. El incremento en el OB y $\mathrm{CO}$ fue sincrónico con la disminución en el número de eventos de El Niño (6 44 cada 100 años) para los últimos 600 años del milenio.

Palabras clave: ópalo biogénico, carbono orgánico, El Niño, La Niña, surgencia.

\section{INTRODUCTION}

Oceanographic conditions in the tropical northwestern Pacific respond with different frequency and intensity to the variability of tropical weather events (Barron et al. 2003, Goni et al. 2006, Barron and Bukry 2007, Flores-Trujillo et al. 2009, Staines-Urías et al. 2009, Marchitto et al. 2010, Pérez-Cruz 2013, Ricaurte-Villota et al. 2013). The variability of marine productivity in the northwestern Pacific during the Holocene has been linked to the following: (1) the position of the subtropical high pressure system (e.g., Goni et al. 2006, Pérez-Cruz 2013); (2) the relative position of the Intertropical Convergence Zone (ITCZ) and the North American Monsoon (e.g., Goni et al. 2006, Staines-Urías et al. 2009, Pérez-Cruz 2013, Ricaurte-Villota et al. 2013); and (3) solar activity, an exogenous factor responsible for El Niño/La Niña-like atmospheric and oceanographic conditions (e.g., Marchitto et al. 2010).

\section{INTRODUCCIÓN}

Las condiciones oceanográficas en el Pacífico nororiental tropical responden con distinta frecuencia e intensidad a la variabilidad de eventos climatológicos (Barron et al. 2003, Goni et al. 2006, Barron y Bukry 2007, Flores-Trujillo et al. 2009, Staines-Urías et al. 2009, Marchitto et al. 2010, PérezCruz 2013, Ricaurte-Villota et al. 2013). La variabilidad de la productividad marina en el Pacífico nororiental durante el Holoceno ha sido explicada por varios mecanismos: (1) la posición del centro de alta presión subtropical (e.g., Goni et al. 2006, Pérez-Cruz 2013); (2) la posición relativa de la Zona de Interconvergencia Tropical y del monzón de Norteamérica (e.g., Goni et al. 2006, Staines-Urías et al. 2009, Pérez-Cruz 2013, Ricaurte-Villota et al. 2013); y (3) la actividad solar, sugerida como factor responsable exógeno de las condiciones atmosféricas y oceanográficas similares a las de El Niño o La Niña (e.g., Marchitto et al. 2010). 
The continental margins of the Baja California peninsula are characterized by high marine biological activity, driven by persistent upwelling of nutrient-rich subsurface waters (Escalante et al. 2013), and a vast oxygen-deficient zone (van Geen et al. 2003). Upwelling and high biological activity promote water-column denitrification at subsurface and intermediate depths (e.g., Álvarez-Borrego 2012, Ricaurte-Villota et al. 2013, Deutsch et al. 2014). During an El Nino event (periodicity of 4 to 7 years), biological activity ceases mainly because of the upwelling of nutrient-poor (among other physicochemical characteristics) waters (Escalante et al. 2013).

The few existing late-Holocene paleorecords from the tropical northwestern region of Mexico are for Guaymas Basin (Barron et al. 2003, Goni et al. 2006, Barron and Bukry 2007), Alfonso Basin (Staines-Urías et al. 2009, Pérez-Cruz 2013, Ricaurte-Villota et al. 2013), and Pescadero Basin (Flores-Trujillo et al. 2009, Staines-Urías et al. 2009) in the Gulf of California, and for Soledad Basin (Marchitto et al. 2010, Deutsch et al. 2014) off the west coast of the Baja California peninsula. Changes in marine productivity and water-column conditions have been linked to changes in solar activity during the late Holocene. In Guaymas and Alfonso basins, diatom production and the flux of biogenic silica and other indicators (titanium and barium/ aluminium ratio) increased during low solar activity (Barron et al. 2003, Barron and Bukry 2007, Pérez-Cruz 2013, Ricaurte-Villota et al. 2013) due to the northward shift of the subtropical high pressure and consequent increased efficiency of northwesterly winds and increased upwelling in this region of the Gulf of California (Goni et al. 2006, Barron and Bukry 2007).

In the southern Gulf of California, the progressive warming of the surface waters over the past 400 years has been associated with the northward shift of the ITCZ due to the increase in solar radiation (Staines-Urías et al. 2009). Moreover, the dinoflagellate Gymnodinium catenatum has inhabited the southern Gulf of California since 1483, and its relative and absolute abundance is positively/negatively modulated by El Niño/La Niña conditions (Flores-Trujillo et al. 2009).

Marchitto et al. (2010) proposed that the variations in sea surface temperature are related to changes in solar activity. These authors suggested that the periods of least solar activity correspond to warm, El Niño-like oceanographic conditions during the early and mid-Holocene, but they did not determine what occurred during the late Holocene and past millennium off the west coast of the Baja California peninsula. This raises some questions about late-Holocene global climate variability and climate variability along the Magdalena Margin (Baja California Sur, Mexico) and its correlation to the variability observed in the tropical or extratropical region over the past 1000 years. The objective of the present study was to determine the variability of marine biological productivity by analyzing organic carbon, calcium
Los márgenes continentales de la península de Baja California se caracterizan por la alta actividad biológica marina, generada por la surgencia persistente de aguas subsuperficiales ricas en nutrientes (Escalante et al. 2013), y por una amplia zona deficiente de oxígeno (van Geen et al. 2003). Las surgencias y la alta productividad biológica marina promueven una columna de agua desnitrificante a profundidades subsuperficial e intermedia (e.g., ÁlvarezBorrego 2012, Ricaurte-Villota et al. 2013, Deutsch et al. 2014). Durante el evento de El Niño (periodicidad de 4 a 7 años), se suprime la productividad biológica marina debido principalmente a la surgencia de agua pobre en nutrientes, entre otras características fisicoquímicas (Escalante et al. 2013).

Los paleoregistros del Holoceno tardío son relativamente escasos en la región tropical nororiental de México y están restringidos a la cuenca de Guaymas (Barron et al. 2003, Goni et al. 2006, Barron y Bukry 2007), la cuenca Alfonso (Staines-Urías et al. 2009, Pérez-Cruz 2013, Ricaurte-Villota et al. 2013) y la cuenca Pescadero (Flores-Trujillo et al. 2009, Staines-Urías et al. 2009) en el golfo de California, y a la cuenca Soledad (Marchitto et al. 2010, Deutsch et al. 2014) en el margen occidental de la península de Baja California. La variabilidad de la productividad marina y las condiciones de la columna de agua han sido asociadas a cambios en la actividad solar durante el Holoceno tardío. En la cuenca de Guaymas y la cuenca Alfonso, la producción de diatomeas y el flujo de sílice biogénico y otros indicadores (titanio y la razón bario/aluminio) incrementaron durante una baja actividad solar (Barron et al. 2003, Barron y Bukry 2007, Pérez-Cruz 2013, Ricaurte-Villota et al. 2013) debido a la migración hacia el norte de la alta presión subtropical, lo cual incrementó la eficiencia de los vientos del noroeste y, por tanto, la incidencia de surgencias en esta región del golfo de California (Goni et al. 2006, Barron y Bukry 2007).

En la región sur del golfo de California, el calentamiento progresivo del agua superficial durante los últimos 400 años fue relacionado con la migración hacia el norte de la Zona de Interconvergencia Tropical debido al incremento en la radiación solar (Staines-Urías et al. 2009). Incluso, el dinoflagelado Gymnodinium catenatum ha estado presente en la región sur del golfo de California desde 1483, y su abundancia relativa y absoluta es modulada positiva/negativamente por condiciones de La Niña/El Niño (Flores-Trujillo et al. 2009).

Marchitto et al. (2010) propusieron que la variabilidad de la temperatura del océano superficial está relacionada con la variabilidad de la actividad solar. Estos autores sugieren que los mínimos solares corresponden a condiciones oceanográficas cálidas similares a El Niño durante el Holoceno temprano y medio, pero no determinaron qué ocurrió en el margen occidental de la península de Baja California durante el Holoceno tardío y el último milenio. Esto deja al descubierto algunas preguntas sobre la variabilidad climática observada durante el Holoceno tardío a nivel global y cómo ésta ocurrió en el margen de Magdalena (Baja California Sur, 
carbonate, and biogenic opal, as well as its relation to the changes in frequency and intensity of El Niño events during the last millennium, when there were two distinct periods of climate change: Medieval Climate Optimum and Little Ice Age.

\section{MATERIALS AND METHODS}

The sediment core from the Magdalena Margin (multicore MAGD-MC02, $42 \mathrm{~cm}$; fig. 1) was extracted during a cruise in October 2009 aboard the R/V New Horizon. It covers approximately the last 1000 years and was sampled at $1-\mathrm{cm}$ intervals to obtain a high-resolution record of organic carbon, biogenic silica, and carbonate content. Organic carbon was determined using a Costech 410 elemental analyzer at the Mass Spectrometry Laboratory (CICIMAR-IPN), and carbonates were determined using a UIC CM5014 carbon dioxide coulometer at the School of Marine Sciences (UABC). Biogenic silica was determined by molybdenum blue spectrophotometry (Mortlock and Froelich 1989).

To determine the age of multicore MAGD-MC02, we used the age model developed by van Geen et al. (2003) and

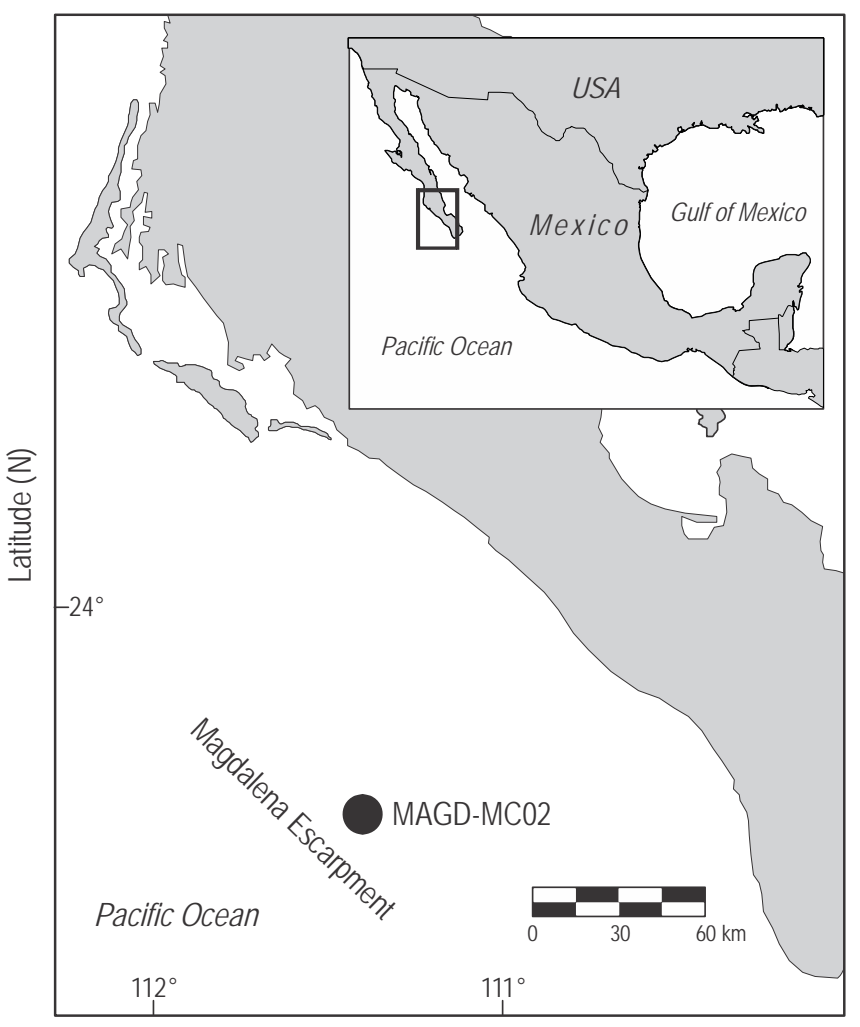

Longitude (W)

Figure 1. Map of the study area showing Magdalena Margin (Baja California Sur, Mexico) and the sampling location of multicore MAGD-MC02.

Figura 1. Área de estudio que muestra el margen de Magdalena (Baja California Sur, México) y la localización del sitio de recolecta del multinúcleo MAGD-MC02.
México) y se correlacionó con la variabilidad observada en la región tropical o extratropical en los últimos 1000 años. El objetivo del presente trabajo fue determinar la variabilidad de la productividad biológica marina, a partir del análisis de carbono orgánico, carbonato de calcio y ópalo biogénico, y su relación con la variabilidad en frecuencia e intensidad de los eventos de El Niño durante el último milenio, cuando ocurrieron dos eventos importantes de cambio climático global: el Óptimo Climático Medieval y la Pequeña Edad de Hielo.

\section{MATERIALES Y MÉTODOS}

El núcleo de sedimento del margen de Magdalena (multinúcleo MAGD-MC02, $42 \mathrm{~cm}$; fig. 1) fue recolectado en octubre de 2009 a bordo del B/I New Horizon, y cubre aproximadamente los últimos 1000 años. Este núcleo fue muestreado a intervalos de $1 \mathrm{~cm}$ para obtener un registro de alta resolución de contenido de carbono orgánico, carbonatos y ópalo biogénico. El carbono orgánico se obtuvo con un analizador elemental Costech 410 en el Laboratorio de Espectrometría de Masas (CICIMAR-IPN). Los carbonatos fueron determinados con un coulómetro de dióxido de carbono (UIC Inc., modelo CM5014) en la Facultad de Ciencias Marinas (UABC). El ópalo biogénico fue determinado por el método espectrofotométrico azul de molibdeno utilizando la técnica de Mortlock y Froelich (1989).

Para determinar la edad del multinúcleo MAGD-MC02, se utilizó el modelo de edad desarrollado por van Geen et al. (2003) y Marchitto et al. (2010), que fue construido utilizando mediciones de radiocarbono $\left({ }^{14} \mathrm{C}\right)$ por espectrometría de aceleración de masas en foraminíferos bentónicos (análisis realizados en el National Ocean Sciences Accelerator Mass Spectrometry Facility en Woods Hole, Massachusetts). Los datos de radiocarbono fueron convertidos en años calendario usando el programa de calibración CALIB 4.3 (Stuvier y Reimer 1993).

\section{RESULTADOS}

Durante los últimos 1000 años del Holoceno tardío, el contenido de ópalo biogénico en el margen de Magdalena varió significativamente, y hubo un incremento gradual hacia el periodo reciente, con los valores mínimos en AD 1378, 1626, 1736 y 1824 (fig. 2a). Los máximos contenidos de ópalo biogénico ocurrieron en los últimos 300 años pero con una mayor variabilidad con respecto a los años previos (fig. 2a). Este incremento gradual del ópalo biogénico durante el Holoceno tardío es consistente con la tendencia en el aumento de carbono orgánico entre AD 1200 y 1750 (fig. 2b); sin embargo, la correlación directamente proporcional y significativa $(R=0.72, P<0.001)$ entre el contenido de ópalo biogénico y el de carbono orgánico (fig. 3a) se volvió inversamente proporcional y significativa $(R=0.58$, $P<0.049)$ en los últimos 250 años del Holoceno tardío (figs. 2a, b; 3b). 
Marchitto et al. (2010), which was constructed by accelerator mass spectrometry radiocarbon (AMS ${ }^{14} \mathrm{C}$ ) dating of benthic foraminifera (conducted at the National Ocean Sciences Accelerator Mass Spectrometry Facility in Woods Hole, Massachusetts). The radiocarbon dates were converted to calendar years using the calibration software CALIP 4.3 (Stuvier and Reimer 1993).

\section{RESUlTS}

During the last 1000 years of the late Holocene, the biogenic opal content of the Magdalena Margin sediments varied considerably, and there was a gradual increase towards the present, with the lowest values in AD 1378, 1626, 1736, and 1824 (fig. 2a). The highest biogenic opal contents occurred in the last 300 years but with greater variability relative to the previous years (fig. 2a). This gradual increase in biogenic opal during the late Holocene is consistent with the increasing trend in organic carbon between AD 1200 and 1750 (fig. 2b); however, the directly proportional and significant correlation $(R=0.72, P<0.001)$ between the biogenic opal and organic carbon contents (fig. 3a) became inversely proportional and significant $(R=0.58, P<0.049)$ in the last 250 years of the late Holocene (figs. 2a, b; 3b).

The calcium carbonate content showed little variation, with a maximum interval of $34 \%$ and minimum of $25 \%$, except for a significant decrease of $\sim 20 \%$ between AD 1560 and 1692 (fig. 2c). The carbonate content showed an inversely proportional and significant correlation with the biogenic opal $(R=0.70, P<0.001$; fig. $3 \mathrm{c})$ and organic carbon contents $(R=0.47, P<0.021$; fig. 3e) between $\mathrm{AD} 1144$ and 1560. After the significant decrease in carbonates, the correlation between the carbonates and biogenic opal was directly proportional and not significant $(R=0.24, P=0.419$; fig. 3d), whereas the correlation between the carbonates and organic carbon was inversely proportional and significant $(R=0.62, P<0.018$; fig. 3f).

\section{DISCUSSION}

\section{Variability of the biogenic components}

The decrease in calcium carbonate content was correlated to an increase in biogenic opal production between AD 1144 and 1560. Based on these observations, the Magdalena Margin experienced a change in the predominance of either calcareous or opaline plankton. This has been observed in the Tropical Eastern Pacific, where there is a considerable increase in opaline plankton (mainly diatoms) during upwelling events and carbonate production is low (Lyle et al. 1988, Thunell et al. 1995, Fisler and Hendy 2008) because of a change in nutrient availability and/or seasonal changes in upwelling (Barron and Bukry 2007, Fisler and Hendy 2008, Marchitto et al. 2010, Barron et al. 2012). However, carbonates and biogenic opal increased from AD 1692 to the present and this contradicts that mentioned previously.

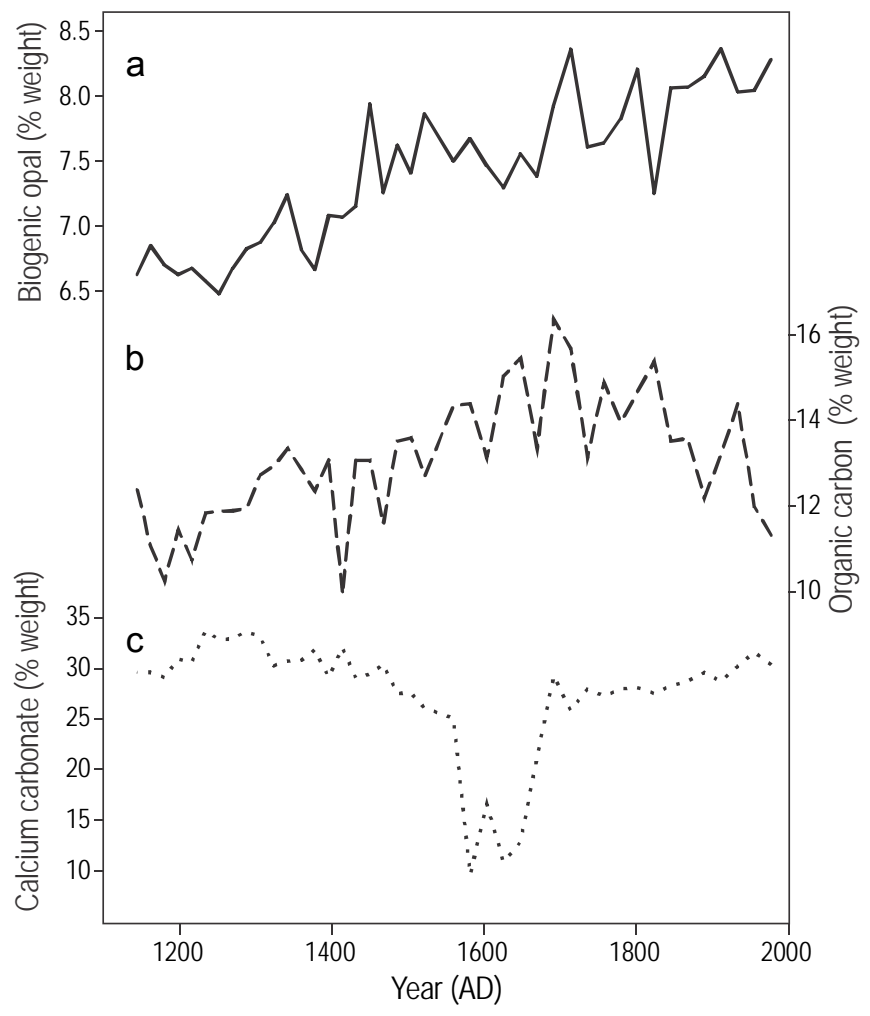

Figure 2. Geochemical indicators of marine biological productivity over the past 900 years of the millennium for the multicore MAGD-MC02: (a) biogenic opal, (b) organic carbon, and (c) calcium carbonate.

Figura 2. Indicadores geoquímicos de la productividad biológica marina durante los últimos 900 años del milenio determinados según los registros del multinúcleo MAGD-MC02: (a) ópalo biogénico, (b) carbono orgánico y (c) carbonato de calcio.

El contenido de carbonatos mostró muy poca variación, con un intervalo máximo de $34 \%$ y mínimo de $25 \%$, a excepción de una disminución significativa de $\sim 20 \%$ entre AD 1560 y 1692 (fig. 2c). El contenido de carbonatos presentó una correlación inversamente proporcional y significativa con el contenido de ópalo biogénico $(R=0.70$, $P<0.001$; fig. 3c) y el de carbono orgánico $(R=0.47$, $P<0.021$; fig. 3e) entre AD 1144 y 1560 . Después de la disminución significativa de carbonatos, la correlación del ópalo biogénico y los carbonatos fue directamente proporcional pero no significativa $(R=0.24, P=0.419$; fig. 3 d $)$, mientras que la correlación entre los carbonatos y el carbono orgánico fue inversamente proporcional y significativa $(R=0.62, P<0.018$; fig. 3f).

\section{DISCUSIÓN}

\section{Variabilidad de los componentes biogénicos}

La disminución en el contenido de carbonato de calcio estuvo correlacionada con un incremento en la producción de 

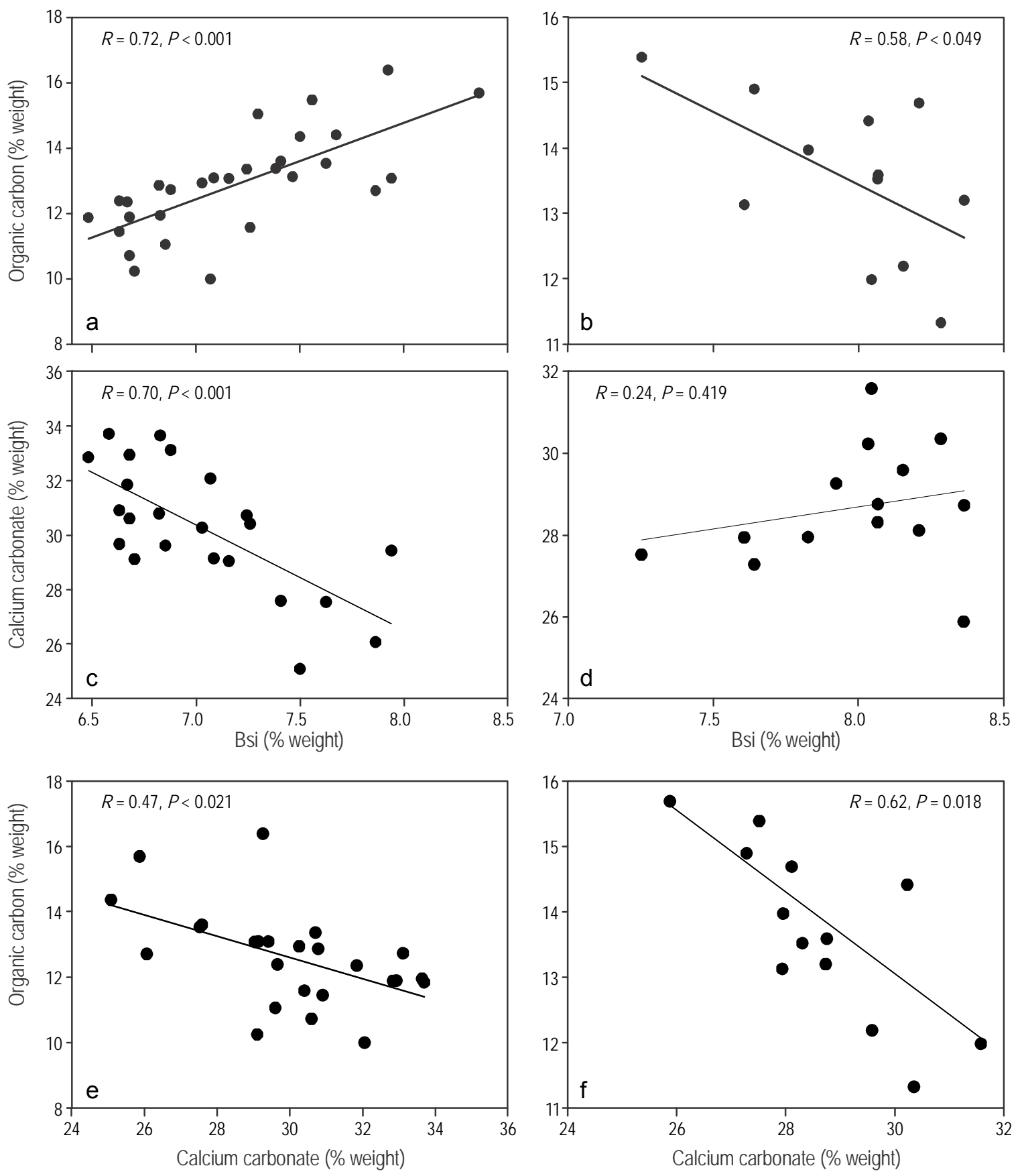

Figure 3. Linear correlation of the indicators of marine biological productivity. Graphs (a), (c), and (e) correspond to the period from AD 900 to 1750 , and graphs (b), (d), and (f) correspond to the last 250 years of the millennium.

Figura 3. Correlación lineal de los indicadores de la productividad biológica marina. Los gráficos (a), (c) y (e) corresponden al período de AD 900 a 1750, y los gráficos (b), (d) y (f) corresponden a los últimos 250 años del milenio.

Carbonate dissolution is one of the factors controlling carbonate content in marine sediments (Jahnke and Jahnke 2004, Morse 2005, Naik and Naidu 2008). It occurs in interstitial water due to organic carbon oxidation and is more intense when a benthic phytodetritic layer is present, especially in marginal regions of highly productive seas (Martin and Sayles 1999, de Villiers 2005); however, the hypothesis ópalo biogénico entre AD 1144 y 1560. Con base en estas observaciones, el margen de Magdalena experimentó un cambio en la dominancia del plancton calcáreo u opalino durante este período. Esto ha sido observado en el Pacífico Tropical Oriental, donde el plancton opalino (principalmente diatomeas) incrementa considerablemente durante los eventos de surgencia y la producción de carbonatos es baja 
of a benthic phytodetritic layer needs to be evaluated in the study area (Sánchez et al. 2013). In the Magdalena Margin sediments, the decrease (increase) in carbonate content corresponds to an increase (decrease) in organic carbon content from AD 1144 to 1560 (AD 1692 to the present). This suggests that organic carbon export variability is responsible for carbonate preservation and accumulation (Naik and Naidu 2010), and supports the idea of low carbonate preservation due to dissolution.

Carbonate dissolution was estimated using the relative abundance of benthic and planktonic foraminifera (foraminiferal dissolution index [FDI], expressed as a ratio of benthic foraminifera to the sum of benthic and planktonic formaminifera; LaMontagne et al. 1996) because benthic foraminifera are more resistant to dissolution than planktonic foraminifera (Ortiz et al. 2004). The correlation between FDI and carbonate content was inversely proportional and significant $(R=0.61, P<0.001)$, the maximumm FDI values corresponding to the lowest carbonate contents (fig. 4). This evidence supports the suspicion of poor carbonate preservation and dissolution due to the oxidation of organic matter, derived from high export productivity, and not to a change in the predominance of calcareous or opaline plankton during this period.

\section{Magdalena Margin and its response to EI Niño during the last millennium}

The Magdalena Margin sedimentary record showed two important changes in marine biological productivity over the past millennium. First, between AD 1100 and 1350, the low biogenic opal and organic carbon contents indicate that productivity declined, which suggests unfavorable upwelling conditions, a weak California Current, and a strengthened and/or eastward-shifted Aleutian Low, similar to El Niño conditions. Second, the constant increase in biogenic opal

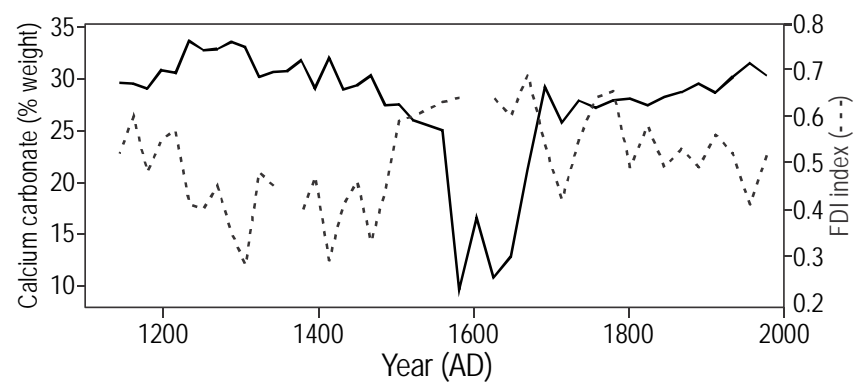

Figure 4. Comparison of the calcium carbonate content and the foraminiferal dissolution index (FDI) over the past 900 years of the millennium for the multicore MAGD-MC02.

Figura 4. Comparación del contenido de carbonato de calcio con el índice disolución de foraminíferos (FDI) durante los últimos 900 años del milenio según los registros del multinúcleo MAGD$\mathrm{MC} 02$.
(Lyle et al. 1988, Thunell et al. 1995, Fisler y Hendy 2008) a causa de un cambio en la disponibilidad de nutrientes y/o cambios estacionales en las surgencias (Barron y Bukry 2007, Fisler y Hendy 2008, Marchitto et al. 2010, Barron et al. 2012). Sin embargo, los carbonatos y el ópalo biogénico incrementaron desde AD 1692 al presente, lo cual contradice lo mencionado anteriormente.

Uno de los factores que controla el contenido de carbonatos en los sedimentos marinos es la disolución de carbonatos (Jahnke y Jahnke 2004, Morse 2005, Naik y Naidu 2008) que ocurre en el agua intersticial debido a la oxidación del carbono orgánico. Esta disolución es más intensa cuando está presente una capa bentónica fitodetrital, especialmente en regiones marginales del océano altamente productivas (Martin y Sayles 1999, de Villiers 2005); sin embargo, la hipótesis de la capa bentónica fitodetrital necesita ser evaluada en el área de estudio (Sánchez et al. 2013). En el margen de Magdalena, la disminución (el aumento) en el contenido de carbonatos se corresponde con el aumento (la disminución) en el contenido de carbono orgánico en el período de AD 1144 a 1560 (AD 1692 al presente). Esto sugiere que la variabilidad en el carbono orgánico exportado es responsable de la preservación y acumulación de carbonatos (Naik y Naidu 2010), y apoya la idea de una baja preservación de carbonatos por disolución.

La disolución de los carbonatos fue estimada utilizando la abundancia relativa de foraminíferos bentónicos y planctónicos (índice de disolución de foraminíferos [IDF], expresado como la relación entre los foraminíferos bentónicos y la suma de foraminíferos bentónicos y planctónicos; LaMontagne et al. 1996) debido a que los foraminíferos bentónicos son más resistentes a la disolución que los foraminíferos planctónicos (Ortiz et al. 2004). La correlación entre el IDF y el contenido de carbonato fue inversamente proporcional y significativa $(R=0.61, P<0.001)$ : los valores máximos de IDF se correspondieron con los contenidos mínimos de carbonatos (fig. 4). Esta evidencia apoya la sospecha de la pobre preservación y disolución de los carbonatos por efecto de la oxidación de la materia orgánica, derivada de la alta productividad marina exportada, y no por un cambio en la dominancia del plancton opalino o calcáreo durante este período.

\section{Margen de Magdalena y su respuesta a El Niño durante el último milenio}

El registro sedimentario del margen de Magdalena mostró dos cambios significativos en la productividad biológica marina en el último milenio. En el primer cambio, durante el período de $\mathrm{AD} 1100$ a 1350, el bajo contenido de ópalo biogénico y carbono orgánico indicaron una disminución en la productividad, lo cual sugiere condiciones poco favorables para el desarrollo de surgencias, una corriente de California débil y una baja presión de las Aleutianas fortalecida y/o más hacia el oriente, similares a las condiciones de El Niño. En el 
and organic carbon contents from $\mathrm{AD} 1400$ to the present suggests favorable upwelling conditions associated with a strengthened California Current and North Pacific highpressure system and fewer El Niño events.

The variability of marine biological productivity in the northwestern Pacific has been associated with the physicochemical conditions of the water column that are modulated seasonally by the movement of the ITCZ and of North Pacific high- and low-pressure systems, and interannually during El Niño and La Niña events. The last millennium was characterized by significant changes in the number of El Niño events. During the first 400 years, there was an average of $15 \pm 7$ El Niño events every 100 years, in contrast to an average of $6 \pm 4$ events every 100 years during the last 600 years (Moy et al. 2002). Moreover, the moderate El Niño regime, established 3000 years ago, is sensitive to changes in climate boundary conditions, including, but not limited to, insolation (Carré et al. 2014).

The low marine productivity observed in the first part of the Magdalena Margin sedimentary record coincides with a warmer sea surface temperature off Oregon and California. This indicates an onshore movement of nutrient-poor subtropical waters and a decline in upwelling off California, except in the Santa Barbara Basin, where upwelling was more intense in spring (Barron and Anderson 2011). The planktonic foraminiferal assemblages experienced important changes over the past 2000 years in Santa Barbara Basin (Fisler and Hendy 2008) and Soledad Basin (Wilsbacher 2007). The presence of subtropical species (Globigerinoides ruber and G. rubescens) coexisting with Neogloboquadrina pachyderma and Globigerina quinqueloba suggests the occurrence of warm anomalous events analogous to an El Niño state. Based on diffuse spectral reflectance, a geochemical tracer of organic carbon deposition (Ortiz et al. 2004), it was possible to identify a recurrence of El Niño and La Niña events during the late Holocene in the eastern North Pacific (Cortina and Herguera 2014).

The presence and abundance of G. quinqueloba is associated with high diatom production (Kincaid et al. 2000, Sautter and Thunell 1991) during a La Niña-like state (Black et al. 2001). In the past millennium, the predominance of G. quinqueloba relative to Globigerina bulloides occurs when subpolar water masses with high nutrient content and low chlorophyll content are advected in the California Current System (Fisler and Hendy 2008). This mechanism for ocean fertilization has been proposed to explain how the biogenic opal content increases due to the advection of water masses in these regions by the leakage of orthosilicic acid (Brzezinski et al. 2002, Matsumoto et al. 2002, Matsumoto and Sarmiento 2008) towards regions limited by this nutrient; this promotes high diatom production throughout the northeastern Pacific on glacial-interglacial timescales (ArellanoTorres et al. 2011). This mechanism for ocean fertilization is considered to be responsible for the increase in biogenic opal segundo cambio, los contenidos de ópalo biogénico y carbono orgánico mostraron un incremento constante a partir de AD 1400 al presente, y esto sugiere condiciones favorables para el desarrollo de surgencias debido al fortalecimiento de un centro de alta presión del Pacífico Norte y de la corriente de California y a una menor incidencia de eventos El Niño.

La variabilidad de la productividad biológica marina en el Pacífico nororiental ha sido asociada al cambio en las condiciones fisicoquímicas de la columna de agua que son moduladas estacionalmente por el movimiento de los centros de alta y baja presión del Pacífico Norte y el movimiento de la Zona de Interconvergencia Tropical, e interanualmente durante los eventos de El Niño y La Niña. El último milenio estuvo caracterizado por cambios significativos en el número de eventos de El Niño. Durante los primeros 400 años, el promedio de eventos El Niño fue de $15 \pm 7$ cada 100 años, lo cual resulta contrastante con el promedio de $6 \pm 4$ eventos cada 100 años durante los últimos 600 años (Moy et al. 2002). Adicionalmente, el régimen moderado de El Niño, establecido desde hace 3000 años, es sensitivo a los cambios en las condiciones de frontera del clima, incluyendo-pero no limitado a-la insolación (Carré et al. 2014).

La baja productividad marina observada en la primer parte del registro sedimentario del margen de Magdalena coincide con una temperatura del océano superficial más cálida frente a Oregón y California. Esto indica una migración de aguas subtropicales pobres en nutrientes hacia la costa y una disminución en la incidencia de surgencias frente a California, excepto en cuenca Santa Bárbara, donde las surgencias de primavera fueron más intensas (Barron y Anderson 2011). La asociación de foraminíferos planctónicos experimentó un cambio significativo durante los últimos 2000 años en cuenca Santa Bárbara (Fisler y Hendy 2008) y cuenca Soledad (Wilsbacher 2007). La presencia de especies subtropicales (Globigerinoides ruber y G. rubescens) que coexisten con Neogloboquadrina pachyderma y Globigerina quinqueloba sugiere la ocurrencia de eventos cálidos anómalos análogos a un estado de El Niño. A partir de la reflectancia espectral difusa, trazador geoquímico del depósito de carbono orgánico (Ortiz et al. 2004), se logró identificar una recurrencia de eventos El Niño y La Niña durante el Holoceno tardío en la región oriental del Pacífico Norte (Cortina y Herguera 2014).

La presencia y abundancia de G. quinqueloba está asociada a una alta producción de diatomeas (Kincaid et al. 2000, Sautter y Thunell 1991) en el océano durante un estado de La Niña (Black et al. 2001). En el último milenio, la dominancia de G. quinqueloba respecto a Globigerina bulloides ocurre cuando masas de agua subpolar con alto contenido de nutrientes y baja concentración de clorofila son advectadas en el Sistema de la Corriente de California (Fisler y Hendy 2008). Este mecanismo de fertilización del océano superficial ha sido propuesto para explicar cómo ocurre el incremento en el contenido de ópalo biogénico debido a la advección de masas de agua de estas regiones mediante la fuga de ácido 


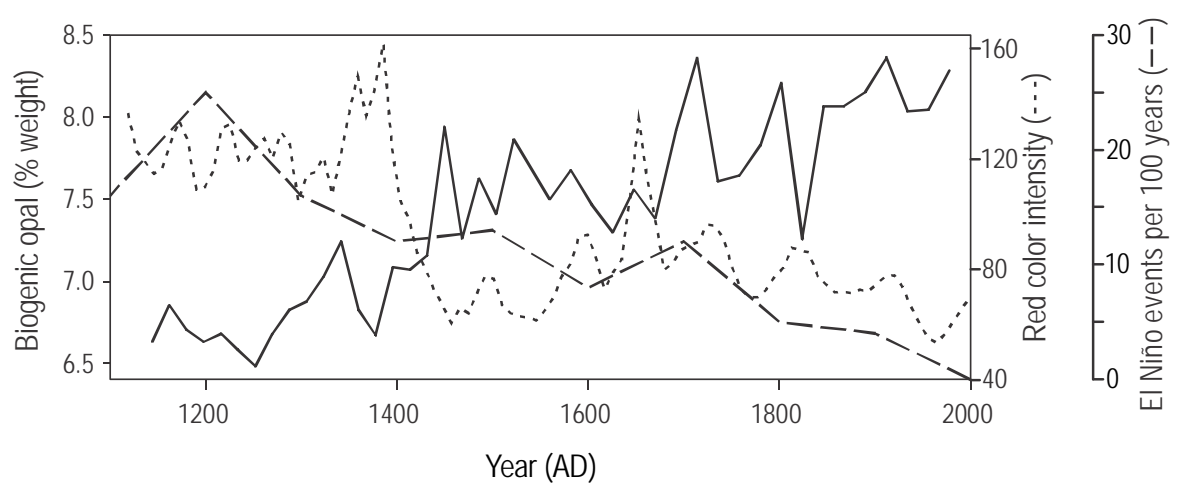

Figure 5. Comparison of the biogenic opal content (solid line) and the intensity of red index and number of El Niño events every 100 years at Laguna Pallcacocha (Ecuador) (Moy et al. 2002).

Figura 5. Comparación del contenido de ópalo biogénico (línea continua) con el índice de la intensidad de color rojo y el número de eventos El Niño cada cien años en la laguna Pallcacocha (Ecuador) (Moy et al. 2002).

content of the Magdalena Margin sediments over the past 600 years.

The constant increase in the content of biogenic opal and organic carbon in the Magdalena Margin sediments (fig. 2a, b) confirms the occurrence of La Niña-like oceanographic conditions over the past 600 years in the northwestern Pacific. In effect, the increase in the indicators of marine biological productivity corresponds to a decrease in the number of El Niño events recorded at Pallcacocha Lagoon in Ecuador (Moy et al. 2002) since AD 1400 (fig. 5). All these records lend support to the evidence that the northwestern Pacific has maintained La Niña-like conditions in the water column during the late Holocene, as well as over the past 600 years, interrupted by some extreme El Niño events.

The variation in calcium carbonate content suggests that the preservation and accumulation of this biogenic component in the Magdalena Margin sediments depends on organic carbon export, and supports the assumption of intense carbonate dissolution between AD 1560 and 1692. Thus, the succession of planktonic groups does not explain the variation in calcium carbonate content in the sediments. The records of biogenic opal and organic carbon content in the Magdalena Margin sediments suggest that marine biological productivity has increased considerably since AD 1400 to the present and coincides with a decrease in the number of El Niño events. The increase in marine biological productivity can be supported by the advection of water masses with high nutrient content from subpolar regions via the California Current System.

\section{ACKNOWLEDGMENTS}

This study was financed by the National Polytechnic Institute (IPN, Mexico, projects SIP20130541 and SIP20140132 to AS) and partially funded by UABC (project 401/1/C/76/17 to OGY). MJ was supported by scholarships ortosilícico (Brzezinski et al. 2002, Matsumoto et al. 2002, Matsumoto y Sarmiento 2008) hacia regiones limitadas por este nutriente; esto promueve una alta producción de diatomeas a lo largo del Pacífico nororiental en una escala de tiempo glaciar-interglaciar (Arellano-Torres et al. 2011). Este mismo mecanismo de fertilización del océano superficial es considerado como responsable del incremento en el contenido de ópalo biogénico en el margen de Magdalena en los últimos 600 años.

El incremento constante en el contenido de ópalo biogénico y carbono orgánico para el margen de Magdalena (fig. 2a, b) confirma que en los últimos 600 años se presentaron condiciones oceanográficas similares a las de un evento La Niña en el Pacífico oriental. En efecto, el incremento observado en los indicadores de la productividad biológica marina se corresponde con una disminución en el número de eventos de El Niño registrado para la laguna Pallcacocha en Ecuador (Moy et al. 2002) a partir de AD 1400 (fig. 5). Estos registros en conjunto soportan la evidencia de que el Pacífico nororiental ha mantenido condiciones en la columna de agua similares a las condiciones durante La Niña en el Holoceno tardío, así como en los últimos 600 años, interrumpidas por algunos eventos extremos de El Niño.

La variabilidad observada en el contenido de carbonato de calcio sugiere que la preservación y acumulación de este componente biogénico en los sedimentos del margen de Magdalena es dependiente del carbono orgánico exportado, y apoya la idea de una intensa disolución de carbonatos entre AD 1560 y 1692. Por tanto, la sucesión de grupos planctónicos no explica la variabilidad del carbonato de calcio en los sedimentos. Los registros del contenido de ópalo biogénico y carbono orgánico en los sedimentos del margen de Magdalena sugieren que la productividad biológica marina ha incrementado significativamente desde AD 1400 hasta el presente, y este incremento es concurrente con la disminución en el número de eventos El Niño. El aumento en la productividad biológica marina puede ser 
from the National Council for Science and Technology (CONACYT) and IPN (BEIFI).

English translation by Christine Harris.

\section{REFERENCES}

Álvarez-Borrego S. 2012. New phytoplankton production as a tool to estimate the vertical component of water exchange between the Gulf of California and the Pacific. Cienc. Mar. 38: 89-99. http://dx.doi.org/10.7773/cm.v38i1A.1885

Arellano-Torres E, Pichevin LE, Ganeshram RS. 2011. Highresolution opal records from the eastern tropical Pacific provide evidence for silicic acid leakage from HNLC regions during glacial periods. Quat. Sci. Rev. 30: 1112-1121. http://dx.doi.org/10.1016/j.quascirev.2011.02.002

Barron JA, Bukry D. 2007. Development of the California Current during the past 12,000 years based on diatoms and silicoflagellates. Palaeogeogr. Palaeoclimatol. Palaeoecol. 248: 313-338. http://dx.doi.org/10.1016/j.palaeo.2006.12.009

Barron JA, Anderson L. 2011. Enhanced Late Holocene ENSO/ PDO expression along the margins of the eastern North Pacific. Quat. Int. 235: 3-12. http://dx.doi.org/10.1016/j.quaint.2010.02.026

Barron JA, Bukry D, Bischoff JL. 2003. A 2000-yr-long record of climate from the Gulf of California. In: West GJ, Blomquist NL (eds.), Proceedings of the 19th PACLIM Workshop, Asilomar, CA, 3-6 March 2002. Technical Report 71 of the Interagency Ecological Program for the San Francisco Estuary, pp. 11-21.

Barron JA, Metcalfe SE, Addison JA. 2012. Response of the North American monsoon to regional changes in ocean surface temperature. Paleoceanography 27: PA3206 http://dx.doi.org/10.1029/2011PA002235

Black DE, Thunell RC, Tappa EJ. 2001. Planktonic foraminiferal response to the 1997-1998 El Niño: A sediment-trap record from the Santa Barbara Basin. Geology 29: 1075-1078. http://dx.doi.org/10.1130/00917613(2001)029<1075:PFRTTE $>2.0 . C O ; 2$

Brzezinski MA, Pride CJ, Franck VM, Sigman DM, Sarmiento JL, Matsumoto K, Gruber N, Rau GH, Coale KH. 2002. A switch from $\mathrm{Si}(\mathrm{OH})_{4}$ to $\mathrm{NO}_{3}^{-}$depletion in the glacial Southern Ocean. Geophys. Res. Lett. 29(12): 1564. http://dx.doi.org/10.1029/2001GL014349

Carré M, Sachs JP, Purca S, Schauer AJ, Braconnot P, AngelesFalcón R, Julien M, Lavallée D. 2014. Holocene history of ENSO variance and asymmetry in the eastern tropical Pacific. Science 345: 1045-1048.

Cortina A, Herguera JC. 2014. Mid-to-Late Holocene organic carbon export variability at the southern boundary of the California Current: An approach based on diffuse spectral reflectance of marine sediment cores. Palaeogeogr. Palaeoclimatol. Palaeoecol. 408: 1-10. http://dx.doi.org/10.1016/j.palaeo.2014.04.015

Deutsch C, Berelson W, Thunell R, Weber T, Tems C, McManus J, Crusius J, Ito T, Baumgartner T, Ferreira V, Mey J, van Geen A. 2014. Centennial changes in North Pacific anoxia linked to tropical trade winds. Science 345: 665-668. http://dx.doi.org/10.1126/science. 1252332

de Villiers S. 2005. Foraminiferal shell-weight evidence for sedimentary calcite dissolution above the lysocline. Deep-Sea Res. (I) 52: 671-680.http://dx.doi.org/10.1016/j.dsr.2004.11.014 soportado por la advección de masas de agua con alto contenido de nutrientes de regiones subpolares vía el Sistema de la Corriente de California.

\section{Agradecimientos}

Este trabajo fue financiado por el Instituto Politécnico Nacional (IPN, proyectos SIP20130541 y SIP20140132 a AS) y parcialmente por la UABC (programa UABC 401/1/C/ 76/17 a OGY). MJ fue apoyada por una beca del Consejo Nacional de Ciencia y Tecnología (CONACYT) y una beca del IPN (BEIFI).

Escalante F, Valdez-Holguín JE, Álvarez-Borrego S, Lara-Lara JR. 2013. Temporal and spatial variation of sea surface temperature, chlorophyll $a$ and primary productivity in the Gulf of California. Cienc. Mar. 39: 203-215. http://dx.doi.org/10.7773/cm.v39i2.2233

Fisler J, Hendy IL. 2008. California Current System response to late Holocene climate cooling in southern California. Geophys. Res. Lett. 35: L09702. http://dx.doi.org/10.1029/2008GL033902

Flores-Trujillo JG, Helenes J, Herguera JC, Orellana-Cepeda E. 2009. Palynological record (1483-1994) of Gymnodinium catenatum in Pescadero Basin, southern Gulf of California, Mexico. Mar. Micropaleontol. 73: 80-89. http://dx.doi.org/10.1016/j.marmicro.2009.06.009

Goni, MA, Thunell RC, Woodwort MP, Muller-Karger FE. 2006. Changes in wind-driven upwelling during the last three centuries: Interocean teleconnections. Geophys. Res. Lett. 33: L15604. http://dx.doi.org/10.1029/2006GL026415

Jahnke RA, Jahnke DB. 2004. Calcium carbonate dissolution in deep sea sediments: Reconciling microelectrode, pore water and benthic flux chamber results. Geochim. Cosmochi. Acta 68: 47-59. http://dx.doi.org/10.1016/S0016-7037(03)00260-6

Kincaid E, Thunell RC, Le J, Lange CB, Weinheimer AL, Reid FMH. 2000. Planktonic foraminiferal fluxes in the Santa Barbara Basin: Response to seasonal and interannual hydrographic changes. Deep-Sea Res. PT II 47: 1157-1176. http://dx.doi.org/10.1016/S0967-0645(99)00140-X

LaMontagne RW, Murray RW, Wei KY, Leinen M, Wang CH. 1996. Decoupling of carbonate preservation, carbonate concentration, and biogenic accumulation: A 400-kyr record from the central equatorial Pacific Ocean. Paleoceanography 11: 553-562. http://dx.doi.org/10.1029/96PA02249

Lyle M, Murray DW, Finney BP, Dymond J, Robbins JM, Brooksforce K. 1988. The record of Late Pleistocene biogenic sedimentation in the eastern tropical Pacific Ocean. Paleoceanography 3: 39-59. http://dx.doi.org/10.1029/PA003i001p00039

Martin W, Sayles F. 1999. Benthic cycling of biogenic components of the particulate flux to the seafloor in the Southern Ocean in March and April 1998. EOS Trans. 80: 241.

Marchitto TM, Muscheler R, Ortiz JD, Carriquiry JD, van Geen A. 2010. Dynamical response of the tropical Pacific Ocean to solar forcing during the early Holocene. Science 330: 1378-1381. http://dx.doi.org/10.1126/science.1194887 
Matsumoto K, Sarmiento JL. 2008. A corollary to the silicic acid leakage hypothesis. Paleoceanography 23: PA2203. http://dx.doi.org/10.1029/2007PA001515

Matsumoto K, Sarmiento JL, Brezeinski MA. 2002. Silicic acid leakage from the Southern Ocean: A possible explanation for glacial atmospheric $\mathrm{pCO}_{2}$. Global Biogeochem. Cycles 16: 5-1-5-23. http://dx.doi.org/10.1029/2001GB001442

Morse JW. 2005. Formation and diagenesis of carbonate sediments. In: Mackenzie FT (ed.), Sediments, Diagenesis, and Sedimentary Rocks. Treatise on Geochemistry, Elsevier, Vol. 7: 67-85.

Mortlock RA, Froelich PN. 1989. A simple method for the rapid determination of biogenic opal in pelagic marine sediments. Deep-Sea Res. (A) 36: 1415-1426. http://dx.doi.org/10.1016/0198-0149(89)90092-7

Moy CM, Seltzer GO, Rodbell DT, Anderson DM. 2002. Variability of El Nino/Southern Oscillation activity at millennial time scales during the Holocene epoch. Nature 420: 162-165. http://dx.doi.org/10.1038/nature01194

Naik SS, Naidu PD. 2008. Possible factors that control calcite dissolution in the western tropical Indian Ocean. Curr. Sci. 95: 22-23.

Naik SS, Naidu PD. 2010. Evaluation of the $\mathrm{CaCO}_{3}$ dissolution proxies in sediment cores from above the lysocline. Quat. Int. 213: 69-73. http://dx.doi.org/10.1016/j.quaint.2008.11.009

Ortiz JD, O'Connell SB, DelViscio J, Dean W, Carriquiry JD, Marchitto T, Zheng Y, van Geen A. 2004. Enhanced marine productivity off western North America during warm climate intervals of the past $52 \mathrm{k} . \mathrm{y}$. Geology 32: 521-524. http://dx.doi.org/10.1130/G20234.1

Pérez-Cruz L. 2013. Hydrological changes and paleoproductivity in the Gulf of California during middle and late Holocene and their relationship with ITCZ and North American Monsoon variability. Quat. Res. 79: 138-151. http://dx.doi.org/10.1016/j.yqres.2012.11.007
Ricaurte-Villota C, González-Yajimovich O, Sánchez A. 2013. Coupled response of rainfall and denitrification to solar forcing during the Holocene in Alfonso Basin. Cienc. Mar. 39: 151-164. http://dx.doi.org/10.7773/cm.v39i2.2224

Sánchez A, González-Yajimovich O, Balart E, López-Ortiz BE, Aguíñiga-García S, Ortiz-Hernández MC. 2013. Acumulación de carbono orgánico total y carbonato de calcio en la zona de oxígeno mínimo del Pacífico nororiental mexicano: Rev. Mex. Cienc. Geol. 30: 222-232.

Sautter LR, Thunell RC. 1991. Planktonic foraminiferal response to upwelling and seasonal hydrographic conditions: Sediment trap results from San Pedro Basin, Southern California Bight. J. Foraminfer. Res. 21: 347-363. http://dx.doi.org/10.2113/gsjfr.21.4.347

Staines-Urías F, Douglas RG, Gorsline DS. 2009. Oceanographic variability in the southern Gulf of California over the past 400 years: Evidence from faunal and isotopic records from planktic foraminifera. Palaeogeogr. Palaeoclimatol. Palaeoecol. 284: $337-354$. http://dx.doi.org/10.1016/j.palaeo.2009.10.016

Stuiver M, Reimer PJ. 1993. Extended ${ }^{14} \mathrm{C}$ data base and revised CALIB $3.0{ }^{14} \mathrm{C}$ age calibration program. Radiocarbon 35 : 215-230.

Thunell RC, Tappa E, Anderson D.M. 1995. Sediment fluxes and varve formation in Santa Barbara Basin, offshore California. Geology 23: 1083-1086. http://dx.doi.org/10.1130/00917613(1995)023<1083:SFAVFI $>2.3 . C O ; 2$

Van Geen A, Zheng Y, Bernhard JM, Cannariato KG, Carriquiry J, Dean WE, Eakins BW, Ortiz JD, Pike J. 2003. On the preservation of laminated sediments along the western margin of North America. Paleoceanography 18: 1098. http://dx.doi.org/10.1029/2003PA000911

Wilsbacher M. 2007. Reconstructing past climate of Soledad Basin from planktonic foraminiferal assemblages. MSc thesis, Department of Geology, Kent State University, 154 pp.

Received October 2014, accepted October 2014. 